\title{
The eradication of Asian longhorned beetle at Paddock Wood, UK
}

\author{
Dominic Eyre ${ }^{1 *}$ (I) and Jane Barbrook ${ }^{2}$
}

\begin{abstract}
In March 2012, an outbreak of Anoplophora glabripennis was detected at Paddock Wood, Kent, UK. The epicentre of the outbreak was adjacent to a site that a company had used for storing imported stone in wood packaging. An eradication campaign was initiated involving the agencies responsible for plant health and forestry in England and Wales. The area was initially surveyed by visual inspection of standing trees from the ground and 24 infested trees were detected. This method was more effective for detecting trees with A. glabripennis exit holes than trees at an early stage of infestation. A further 42 infested trees were detected when the infested trees and host trees within $100 \mathrm{~m}$ of them were felled and the felled material was inspected. The most important host tree species was Acer pseudoplatanus (43 of the 66 infested trees). Tree climbers inspected the trees between 100 and $300 \mathrm{~m}$ of infested trees three times. They found damage caused by native pests that it had not been possible to detect from the ground but no $A$. glabripennis. Other surveillance techniques used were the regular inspection of favoured host trees over a wide area and the planting and regular inspection of favoured host trees in the core of the outbreak area. Pheromone trapping and the use of detection dog teams were trialled during the outbreak. Public meetings, leaflet drops, press releases, television features and school visits were all used to communicate with local residents and other stakeholders. No $A$. glabripennis were detected after the initial removal of trees in 2012 and eradication was declared after seven years of surveillance in 2019. The outbreak was likely to have been present for 10 or 11 years, but population development is likely to have been limited by the sub-optimal climatic conditions, especially the UK's relatively cool summers.
\end{abstract}

Keywords: Anoplophora glabripennis, Eradication, Tree, Invasive, Cerambycidae

\section{Introduction}

Eradication is the last strategy available to National Plant Protection Organisations (NPPOs) for preventing the permanent establishment of a plant pest and it can be employed when other preventative measures, such as phytosanitary measures restricting imports have failed. In a plant health context, eradication is defined as 'Application of phytosanitary measures to eliminate a pest from an area' (IPPC 2018). Eradication campaigns can take many years (Eyre and Haack 2017), are likely to require considerable resources and require the support

*Correspondence: dominic.eyre@defra.gov.uk

${ }^{1}$ Department for Environment, Food and Rural Affairs, Room 11G19, Sand Hutton, York YO41 1LZ, UK

Full list of author information is available at the end of the article and commitment of stakeholders and officials. Other essential elements of a plant health eradication campaign include effective tools for detecting the pest and a means of controlling it and these will be determined by the biology of the pest (Brockerhoff et al. 2010; Simberloff 2002; Tobin et al. 2014). The effectiveness, ease of use, public acceptability and cost of different detection and control methods will be important in determining whether eradication is likely to be successful. Eradication programmes against forest pests are often unsuccessful, because of shortcomings in one or more of these areas. Carnegie and Nahrung (2019) gathered information on the outcome of responses to 34 exotic forest pests detected in Australia between 1996 and 2017. At the time the paper was written, only one of the pests had been successfully

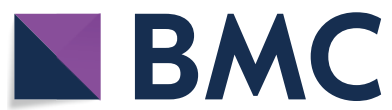

(c) The Author(s) 2021. This article is licensed under a Creative Commons Attribution 4.0 International License, which permits use, sharing, adaptation, distribution and reproduction in any medium or format, as long as you give appropriate credit to the original author(s) and the source, provide a link to the Creative Commons licence, and indicate if changes were made. The images or other third party material in this article are included in the article's Creative Commons licence, unless indicated otherwise in a credit line to the material. If material is not included in the article's Creative Commons licence and your intended use is not permitted by statutory regulation or exceeds the permitted use, you will need to obtain permission directly from the copyright holder. To view a copy of this licence, visit http://creativeco mmons.org/licenses/by/4.0/. The Creative Commons Public Domain Dedication waiver (http://creativecommons.org/publicdomain/ zero/1.0/) applies to the data made available in this article, unless otherwise stated in a credit line to the data. 
eradicated, because, in most cases, either the pests were not detected early enough for eradication to be feasible or they were considered unlikely to cause significant damage.

The first, and to date, only known UK outbreak of Anoplophora glabripennis Motschulsky (Coleoptera: Cerambycidae), commonly known as Asian longhorned beetle was confirmed in Kent in 2012. Kent is in the south-east corner of England. By 2012, there had already been 16 years' of experience of attempts to eradicate the pest in North America following its discovery in New York in 1996 (Haack et al. 1997) and 11 years following its discovery in Austria in 2001 (Tomiczek et al. 2002). Past eradication campaigns included extensive research programmes which provided valuable information on the characteristics of $A$. glabripennis as an invasive pest. For example, laboratory studies on the relationship between the rate of development and temperature (Keena 2002; Keena 2006; Keena and Moore 2010) which provided information on A. glabripennis development in locations where populations have not been known before. By 2012 there were many A. glabripennis host records available from North America, Europe and Asia (Haack et al. 2010; Hérard et al. 2006; Hu et al. 2009). Data on A. glabripennis host preferences were very important to ensure that high risk trees were prioritised for survey and removal in any infested areas. Some of the available literature (Haack et al. 2010; Nehme et al. 2010), also provided information on the efficacy of different survey techniques and the preferred feeding sites for A. glabripennis within host plants. Other authors had studied the ability of A. glabripennis to spread during outbreaks (Sawyer 2007; Smith et al. 2001). Dispersal studies allow risk managers to determine appropriate areas for delimitation surveys and zones where susceptible trees need to be removed.

On 1st March 2012, in the weeks before the outbreak of A. glabripennis in Kent was declared, the European Union published emergency legislation, which set out revised measures on how to reduce the likelihood of the introduction and spread of citrus longhorn beetle, Anoplophora chinensis Forster (2012/138/EU). This legislation included the actions member states needed to take to eradicate or contain outbreaks of the pest. A. glabripennis and $A$. chinensis are distinct species, but with overlapping host ranges (Sjöman et al. 2014), geographic ranges, biology, ecology and status as invasive pests (Haack et al. 2010). Therefore, the emergency measures for A. chinensis provided a useful guide to appropriate action to take to eradicate $A$. glabripennis.

The initial site of infestation at Paddock Wood was adjacent to the premises of a stone importer that had stored wooden crates associated with imported stone. The company had been operating at the site for at least
12 years before it relocated in 2010. In 2007, an amateur entomologist reported seeing an adult A. glabripennis approximately $0.5 \mathrm{~km}$ north of the site, but the beetle was not caught and the record could not be verified. In October 2009, an adult A. glabripennis was caught in a garden adjacent to the location of the stone importer and reported to the NPPO (at the time this was the Food and Environment Research Agency). This finding initiated surveys of the surrounding area which were conducted by the Forestry Commission (FC). No evidence of $A$. glabripennis infestation was detected in 2009, 2010 and 2011. However in February 2012, scientists from Forest Research joined FC for what had been planned as the final year of the survey. Cerambycid larvae were detected in a Salix cinerea tree on the opposite side of a main road from the garden where the beetle was found in 2009. The larvae were subsequently confirmed as A. glabripennis at the Forest Research laboratory at Alice Holt, Hampshire (Straw et al. 2014).

In this paper we will describe the methods and experiences of the UK plant health service in the eradication of A. glabripennis. The outbreak area was typical of rural England and included agricultural fields, small woodlands, orchards, residential and commercial properties, on flat land at a low altitude (14 m asl).

\section{Outbreak management processes and the sequence of activities}

The management of the outbreak in Kent was delivered by a multi-agency response. The outbreak was first detected by scientists from Forest Research (FR), the agency responsible for scientific support of forestry. FR advised on outbreak management, diagnosed samples and carried out research to develop an understanding of the biology of A. glabripennis and the development of the outbreak in UK conditions. The Forestry Commission (FC) contracted private companies to remove the infested trees and supervised this work. FC is the agency responsible for managing forests in Great Britain. The outbreak occurred three years after the formation of the Food and Environment Research Agency (FERA) which incorporated the Plant Health and Seeds Inspectorate (PHSI) responsible for operational non-forestry plant health work in England and Wales (not Scotland and Northern Ireland), diagnostic, research and advisory scientists, plus the staff responsible for plant health policy in England and functioning as the NPPO for the United Kingdom. The PHSI were responsible for surveillance at Paddock Wood. Scientific and diagnostic staff at FERA provided advice on outbreak management, sought advice from international colleagues, assisted with inspection work and carried out further research work. In 2014, the agencies responsible for plant health in England were 
reorganised, plant health research and diagnosis continued in Fera Science Ltd., plant health policy and scientific advisory functions were moved into the Department for Environment Food and Rural Affairs (Defra) and the PHSI became part of the newly formed Animal and Plant Health Agency. Defra represents the UK on plant health matters internationally and is responsible for plant health policy in England, but domestic issues are dealt with separately by Wales, Scotland and Northern Ireland.

At the time the outbreak of A. glabripennis was discovered, there were no EU requirements on managing outbreaks of the pest in the EU, these were not published until 2015 (EU 2015). The main guidance used for the measures taken were the emergency measures published for A. chinensis (EU 2012) and the experience from other EU countries and other countries around the world of managing outbreaks of $A$. glabripennis. The plan for eradication was based on a UK draft contingency plan for A. chinensis and the initial actions were to:

(i) Survey from the ground all deciduous trees within $500 \mathrm{~m}$ of any infested trees.

(ii) Demarcate an 'infested area' which extended to $100 \mathrm{~m}$ from any infested tree and remove and destroy host plants in this area.

(iii) Demarcate a 'buffer zone' with a radius of $2 \mathrm{~km}$ around the infested area, and prohibit the movement of potentially infested material outside of this area.

The sequence of key events during the early stages of the outbreak at Paddock Wood is set out in Table 1. The outbreak management board was chaired by the head of the NPPO and included input from the inspectors working on site, the managers of the inspectors, scientific advisors and diagnosticians from FERA and FR, the FC staff responsible for the tree removal and communications/media teams. Members of this group met daily at first, and then weekly after the first month.

The initial response in 2012, was followed immediately by a comprehensive annual surveillance programme (Table 2) based on the principle that it should continue for a period covering at least two lifecycles of the pest. This included ground surveillance of all trees out to a distance of $800 \mathrm{~m}$ from infested trees (Fig. 1).

The lifecycle of $A$. glabripennis in Kent was considered to be 2-3 years, with three years the most likely (Straw et al. 2015), so the initial plan was to survey for six years until 2018 before declaring eradication. However, due to resource constraints, survey work planned for 2018 was spread over two years, which meant that eradication was not declared until 2019.

The response to this outbreak required much greater cross agency co-operation than had previously been necessary. Many of the individuals involved had not worked together before and there was some difference in normal working culture between the people who dealt with statutory plant health responses as the core part of their job and scientific researchers. This meant there were some challenges when it came to determining operational responsibilities, sharing data and delivering a consistent and coherent message to stakeholders. None of the agencies had previously worked on an eradication campaign for an invasive longhorn beetle which increased the need for sharing existing skills and experience and seeking

Table 1 Sequence of events of eradiation campaign versus A. glabripennis in 2012

\begin{tabular}{|c|c|}
\hline Date & Event \\
\hline Late Feb & Scientists from Forest Research in the UK detected longhorn beetle larvae during surveys at Paddock Wood \\
\hline 15 March & The larvae were confirmed as A. glabripennis \\
\hline 20 March & The National Plant Protection Organisation was informed of the finding \\
\hline 21 March & FERA Plant Health \& Seeds inspectors visited the outbreak site \\
\hline 22 March & An outbreak management board met to discuss the outbreak \\
\hline 28 March & $\begin{array}{l}\text { Systematic surveys of the infested area (within } 100 \text { m of infested trees), and an inner buffer zone (100-500 m of } \\
\text { infested trees) began }\end{array}$ \\
\hline 2 April & Staff from the Forestry Commission (FC) met with contractors on site to discuss tree removal operations \\
\hline 12 April & FC met with arboricultural professionals from the area to show them the damage and ask them to look out for the pest \\
\hline 16 April & Work to remove infested and potentially infested trees began \\
\hline 18 April & The list of tree species for removal was confirmed \\
\hline 25 April & A meeting with local residents was held \\
\hline 3 August & The cutting down of infested and potentially infested trees was completed \\
\hline 8 August & The incineration of infested and potentially infested trees after thorough inspection was completed \\
\hline 10 August & Ten pheromone traps were put up in host trees in the demarcated area \\
\hline 21 August & The detection dog team arrived from Austria \\
\hline
\end{tabular}


Table 2 Programme of surveillance activities at Paddock Wood from 2012-2019

\begin{tabular}{|c|c|c|c|c|c|c|c|c|c|}
\hline $\begin{array}{l}\text { Activity } \\
\text { (responsible } \\
\text { organisation) }\end{array}$ & $\begin{array}{l}\text { Distance } \\
\text { from infested } \\
\text { trees/location }\end{array}$ & $\begin{array}{l}\text { March-end } \\
\text { June } 2012\end{array}$ & $\begin{array}{l}\text { July 2012- } \\
\text { June } \\
2013\end{array}$ & $\begin{array}{l}\text { July 2013- } \\
\text { June } \\
2014\end{array}$ & $\begin{array}{l}\text { July 2014- } \\
\text { June } \\
2015\end{array}$ & $\begin{array}{l}\text { July 2015- } \\
\text { June } \\
2016\end{array}$ & $\begin{array}{l}\text { July 2016- } \\
\text { June } \\
2017\end{array}$ & $\begin{array}{l}\text { July 2017- } \\
\text { June } \\
2018\end{array}$ & $\begin{array}{l}\text { July 2018- } \\
\text { June } \\
2019\end{array}$ \\
\hline \multirow{4}{*}{$\begin{array}{l}\text { Visual survey } \\
\text { from ground } \\
\text { (PHSI) }\end{array}$} & $0-100 \mathrm{~m}$ & Y & & Y & Y & Y & Y & Y & \\
\hline & $100-500 \mathrm{~m}$ & $Y^{b}$ & Y & Y & Y & Y & Y & Y & \\
\hline & $500-800 \mathrm{~m}$ & & & Y & & Y & & & Y \\
\hline & $\begin{array}{l}\text { Area around } \\
\text { local waste } \\
\text { disposal } \\
\text { sites }\end{array}$ & Y & & Y & & & & & \\
\hline $\begin{array}{l}\text { Visual survey of } \\
50 \text { favoured } \\
\text { host trees } \\
\text { (PHSI) }\end{array}$ & $100-2500 \mathrm{~m}$ & & Y & $Y$ & Y & Y & Y & Y & Y \\
\hline $\begin{array}{l}\text { Tree climber } \\
\text { Survey (Con- } \\
\text { tractor/PHSI) }\end{array}$ & $100-300 \mathrm{~m}^{c}$ & & & Y & $\begin{array}{l}\text { Only suspi- } \\
\text { cious trees }\end{array}$ & Y & $\begin{array}{l}\text { Only suspi- } \\
\text { cious trees }\end{array}$ & Y & \\
\hline $\begin{array}{l}\text { Inspection of } \\
\text { trap trees/ } \\
\text { re-growth } \\
\text { of sycamore } \\
\text { hedge (FR) }\end{array}$ & & & & & Y & Y & Y & Y & Y \\
\hline $\begin{array}{l}\text { Pheromone } \\
\text { trapping } \\
\text { (FERA/PHSI) }\end{array}$ & & & Y & $Y$ & Y & Y & Y & Y & Y \\
\hline
\end{tabular}

a PHSI = Plant Health and Seeds Inspectorate, FR = Forest Research, FERA = Food and Environment Research Agency

${ }^{b}$ This area was surveyed twice between April-end June 2012

c Some of these areas were also inspected by the detection dog team from Austria in 2012

advice from contacts in other countries. Some of the difficulties were resolved by the development of informal relationships and the sharing of expertise between individuals in different organisations who had not previously worked together. More formally, some of the challenges were overcome by the establishment of procedures and organisational structures for managing the outbreak. This formalised decision making processes and determined responsibilities for different areas of work. The daily internal reporting templates changed over time to include communications and media issues. The concept of a 'common operating picture' was incorporated into working practices. This is a process in which information from multiple sources is collected and the current status of an incident is collectively agreed. Implementing this concept helped to improve internal and external communication about the outbreak. The experience gained during this outbreak highlighted the need for a more formalised approach to outbreak management and contributed to the development and publication of a greatly revised generic contingency plan for plant and bee health in England in 2017 (Defra 2017). The input of inspectors across all operational regions in England and Wales (the nations where the PHSI are responsible for plant health inspections) into surveillance at Paddock Wood ensured that there was resilience for any further finds of A. glabripennis in other regions.

\section{Host classification}

One of the early tasks for the outbreak management team was to categorise the status of potential host trees at Paddock Wood in terms of their risk of infestation with $A$. glabripennis. This was done by evaluating host records from Asia, North America and Europe (Hérard et al. 2006, 2009; Lingafelter and Hoebeke 2002; MacLeod et al. 2012) and the host list for the USA which has since been updated (APHIS 2015). The categorised list was produced at the level of plant genus. Records from continental Europe were considered to be the most reliable guide to the plant genera that could become infested in the UK because they were more likely to refer to the same species as those found in the UK. This task was important for establishing which trees needed to be removed, which needed to be inspected and which could be safely planted as replacements for any felled trees.

Table 3 shows the classification of hosts according to the risk of infestation by $A$. glabripennis that was used for the management response at Paddock Wood. The broadleaved trees that were present in the infested area (within $100 \mathrm{~m}$ of infested trees) at Paddock Wood and 




Fig. 1 Map of areas demarcated for surveillance for A. glabripennis at Paddock Wood in 2013 ( ${ }^{\circ} \mathrm{Crown}$ Copyright and database rights 2013. Ordnance Survey Licence number 100051110) 
Table 3 Categorisation of hosts of A. glabripennis used for outbreak management in 2012-broadleaved trees recorded in the infested zone are shown in bold

\begin{tabular}{ll}
\hline Category & Tree genera and species \\
\hline High risk & Acer, Aesculus, Betula, Populus, Salix, Ulmus \\
Less favoured & $\begin{array}{c}\text { Albizia, Alnus, Carpinus, Cercidiphyllum japonicum, Corylus, Fagus, Fraxinus, Koelreuteria paniculata, Platanus, Prunus (excl. } \\
\text { P. laurocerasus), Robinia pseudoacacia, Sophora, Sorbus, Quercus palustris, Quercus rubra }\end{array}$ \\
Rare or questionable hosts & $\begin{array}{c}\text { Catalpa, Celtis occidentalis, Eleagnus, Ginko biloba, Hibiscus syriacus, Liquidambar styraciflua, Liriodendron tulipfera, Malus, } \\
\text { Melia azedarach, Morus, Prunus laurocerasus, Pyrus, Rosa, Tilia } \\
\text { Non host species } \\
\text { Ailanthus altissima, Castanea, Cornus, Crataegus, Euonymus, Gleditsia, Hamamelis, llex, Juglans, Magnolia, Ostrya, Quercus } \\
\text { robur, Quercus petraea, Rhamnus, Sambucus, Syringa, Viburnum }\end{array}$ \\
\hline
\end{tabular}

had a stem of at least $2 \mathrm{~cm}$ at $1 \mathrm{~m}$ above ground level are shown in bold. This classification was determined by scientists from Forest Research and FERA on the basis information published up until April 2012. Any plants categorised as 'high risk' or 'less favoured' and present in the infested area were removed.

\section{Surveillance \\ Ground based visual inspection surveys for demarcation and follow up surveys}

Teams of inspectors from the PHSI carried out initial ground inspections in 2012 and in subsequent years. Trees in the 'high risk', 'less favoured' and 'rare or questionable host' categories of Table 3 were surveyed. Inspectors looked for external signs of A. glabripennis including host trees with exit holes, oviposition pits, frass (sawdust like excrement), and exposed feeding galleries/ tunnelling. Symptoms including damaged or hollow bark, bark fissures, dead branches and tree decline were also inspected and sampled as appropriate. Trees and hedgerows were inspected on private land, at commercial premises, residential properties, and along roadsides and railways. Lightweight binoculars (with a magnification of $10 \times 32$ recommended) were used to facilitate inspections of larger trees. A spotting scope on a tripod was also used. Inspectors were advised to stand at distance from trees when inspecting and to take breaks to prevent muscular and skeletal strain or fatigue. The second element of the visual inspection survey involved inspection of all felled material. This is described in the 'Pest management procedures' section.

The local inspector responsible for the outbreak organised inspectors into teams of 3-4, each with an experienced team lead. For follow-up annual ground surveys, teams worked over a period of 8 weeks post leaf fall in late November-February, looking for exit holes and suspicious signs across pre-defined zones within the demarcated areas. Regional resource was stretched and the survey was delivered by complementing the local team with inspectors from across England and Wales visiting for short periods.

A planned, co-ordinated approach to survey was devised. The demarcated zones were sub-divided into fourteen zones bounded by identifiable features on the ground, which meant several teams could work independently on different areas at the same time, and inspection progress and resourcing needs were easier to monitor and record. Suspect trees were physically tagged and sampled and a recording sheet was developed to record findings, together with progress mapping based on the areas. Details of suspect trees, including photos, were recorded in the field and, in later years, recorded in the field using iPads. A meeting at the beginning and end of each day ensured a review of survey progress, input to the next day's planning and an opportunity to raise any questions or issues by the teams.

A total of 2133 trees were removed from the infested zone in 2012 as part of the outbreak response, of these $66(3.1 \%)$ were confirmed to be infested. Table 4 shows a summary by tree species of the life stages found. The infested area covered 11.4 ha. No infested trees were detected after August 2012. The infestation was detected in $24(36 \%)$ of these trees during visual inspection of standing trees from the ground and the infestation in the remaining 42 trees was detected by the inspection of their trunk and branches after they had been felled. A higher proportion of the infested trees which had exit holes $(68 \%)$ were detected during visual inspections of standing trees from the ground than those without exit holes (23\%) (Straw et al. 2014) demonstrating that visual inspection from the ground was less effective for recently infested trees. A total of 1346 stem and branch samples were moved from the field site to the quarantine facility and of these 845 had galleries or tunnels, 256 contained dead or live larvae, pupae or adult $A$. glabripennis and 247 contained exit holes likely to be $A$. glabripennis. Analysis of wood samples revealed that the outbreak had probably been initiated in around 2001 or 2002 (Straw et al. 2016) and by 2012 it had spread about $230 \mathrm{~m}$ in a 
Table 4 Life stages of A. glabripennis found alive at Paddock Wood between April and August 2012 (Straw et al. 2014, 2016)

\begin{tabular}{|c|c|c|c|c|c|c|c|}
\hline Host genus & $\begin{array}{l}\text { No infested } \\
\text { trees }\end{array}$ & Tree species & $\begin{array}{l}\text { No. infested trees/ } \\
\text { removed }^{\mathrm{a}}\end{array}$ & $\begin{array}{l}\text { Larvae } \\
(<10 \mathrm{~mm})\end{array}$ & $\begin{array}{l}\text { Larvae } \\
(>10 \mathrm{~mm})\end{array}$ & $\begin{array}{l}\text { Live pupae/ } \\
\text { adults }\end{array}$ & Adult exit holes \\
\hline \multirow[t]{3}{*}{ Acer } & 53 & A. pseudoplatanus & $43(168)$ & 9 & 252 & 36 & 555 \\
\hline & & A. campestre & $9(342)$ & 0 & 4 & 0 & 3 \\
\hline & & A. negundo & $1(6)$ & 2 & 0 & 0 & 0 \\
\hline \multirow[t]{3}{*}{ Salix } & 7 & S. fragilis & $4(66)$ & 77 & 8 & 0 & 2 \\
\hline & & S. cinerea & $2(10)$ & 0 & 10 & 0 & 3 \\
\hline & & S. caprea ${ }^{\text {b }}$ & $1(9)$ & 0 & 0 & 0 & 0 \\
\hline Betula & 3 & B. pendula & $3(39)$ & 0 & 2 & 0 & 0 \\
\hline Populus & 2 & Populus $\times$ canadensis & $2(74)$ & 1 & 0 & 0 & 1 \\
\hline Aesculus & 1 & A. hippocastanum & $1(4)$ & 0 & 1 & 0 & 0 \\
\hline Total & & & $66(718)$ & 89 & 277 & 36 & 564 \\
\hline
\end{tabular}

a The figure in brackets is the number of trees in each species that were present and cut down from the infested area

b Although no live stages were found in this tree other signs of infestation were found including dead/missing larvae, empty oviposition pits and egg-laying sites with no further development

northerly direction and about $110 \mathrm{~m}$ in a southerly direction. Most of the spread took place along two lines of trees that bordered a major road running north to south.

The most heavily infested host tree species at Paddock Wood was Acer pseudoplatanus (sycamore is the common name for this tree in the UK), $98 \%$ of the exit holes found at the site were in trees of this species. A single $A$. pseudoplatanus tree at the centre of the outbreak had 498 exit holes, representing $90 \%$ of the exit holes from $A$. pseudoplatanus trees and $89 \%$ of all the exit holes discovered during the outbreak (Table 4).

The infested trees varied significantly in size, the smallest having a diameter at breast height $(\mathrm{dbh})$ of $5 \mathrm{~cm}$ and the largest with a dbh of $100 \mathrm{~cm}$, the majority having a dbh of $10-20 \mathrm{~cm}$. The infestations were found in branches between $2.1 \mathrm{~cm}$ and $61.5 \mathrm{~cm}$ in diameter, but most occurred in stems and branches with a diameter of 4-10 cm (Straw et al. 2014).

Visual inspection of standing trees in 2012 led to the detection of 24 (36\%) of the A. glabripennis infested trees at Paddock Wood. The rest of the infested trees were identified after they had been felled and cut up into sections and these infested sections were examined before disposal. The $36 \%$ detection rate compares with a detection rate of about $20 \%$ noted by Nehme et al. (2011) in Massachusetts, USA, 32\% in Chicago, USA (Joseph McCarthy, pers. comm.) and 33\% in Germany (Julius Kuhn-Institut 2014). Turgeon et al. (2010) tested the efficacy of ground based surveys for A. glabripennis by creating simulated oviposition pits and exit holes at heights up to $6 \mathrm{~m}$ on open grown Acer platanoides. The trees had an average height of $12 \mathrm{~m}$. The simulated signs of injury were placed at varying densities and heights from the ground. In this study the efficacy of ground inspection was very high (around 81\% for oviposition pits and 74\% for exit holes), although the efficacy might be expected to be lower for taller trees or in situations where the foliage of the trees overlaps.

After seven years of surveying with no further $A$. glabripennis detected at Paddock Wood, eradication was finally declared in 2019. The eradication was communicated in a press release (Defra 2019), on the portal of the International Plant Protection Convention and EPPO Global Database (EPPO 2019b). This extended period of intense surveillance was necessary to provide re-assurance that the pest had been eradicated from the area, because there have been instances of A. glabripennis being found in an area after many years of no finds such as in Toronto, Canada where a satellite outbreak was discovered just outside the previously regulated area (Turgeon et al. 2015).

One of the signs of the presence of A. glabripennis that had proved useful to inspectors in other parts of Europe, the presence of frass ejected by larvae from host trees, proved less useful in the UK. The relatively low number of infested trees at Paddock Wood and the fact that most of the life stages found for the whole outbreak were restricted to a single tree makes it difficult to draw firm conclusions about any potential differences in signs in the UK as opposed to other countries. However, if the observations of inspectors at Paddock Wood are a reflection of differences, these could relate to the slow development of A. glabripennis at Paddock Wood compared with its development rate in areas where the climate is warmer (Straw et al. 2015). The sub-optimal climate, especially the UK's relatively cool summers and relative scarcity of the favoured host, A. pseudoplatanus are thought likely to have been the main factors in the 
Table 5 Uninfested tree species that were removed at Paddock Wood (Straw et al. 2014)

\begin{tabular}{|c|c|c|c|c|}
\hline & Genus & $\begin{array}{l}\text { Uninfested } \\
\text { trees in } \\
\text { genus }\end{array}$ & Species & No. trees \\
\hline \multirow{7}{*}{$\begin{array}{l}\text { Species with } \\
\text { infested spe- } \\
\text { cies in same } \\
\text { genus }\end{array}$} & Acer & 15 & platanoides & 11 \\
\hline & Acer & & palmatum & 4 \\
\hline & Betula & 6 & $\begin{array}{l}\text { utilis var jacque- } \\
\text { montii }\end{array}$ & 6 \\
\hline & Populus & 160 & $\begin{array}{l}\text { trchocarpa 'Balsam } \\
\text { Spire' }\end{array}$ & 151 \\
\hline & Populus & & tremula & 9 \\
\hline & Salix & 2 & $\begin{array}{l}\text { babylonica'Tor- } \\
\text { tuosa' }\end{array}$ & 2 \\
\hline & Sub-total & & & 183 \\
\hline \multirow{21}{*}{$\begin{array}{l}\text { Species with } \\
\text { no infested } \\
\text { trees in } \\
\text { genus }\end{array}$} & Alnus & 367 & incana & 250 \\
\hline & Alnus & & hybrida & 51 \\
\hline & Alnus & & cordata & 37 \\
\hline & Alnus & & glutinosa & 29 \\
\hline & Carpinus & 148 & betulus & 148 \\
\hline & Corylus & 198 & avellana & 198 \\
\hline & Fagus & 64 & sylvatica & 64 \\
\hline & Fraxinus & 83 & excelsior & 83 \\
\hline & Prunus & 329 & spinosa & 218 \\
\hline & Prunus & & avium (cultivated) & 28 \\
\hline & Prunus & & $\begin{array}{l}\text { domestica ssp. } \\
\text { insititia }\end{array}$ & 28 \\
\hline & Prunus & & avium (wild type) & 22 \\
\hline & Prunus & & cerasifera & 17 \\
\hline & Prunus & & serrulata & 11 \\
\hline & Prunus & & $\begin{array}{l}\text { domestica ssp. } \\
\text { domestica }\end{array}$ & 5 \\
\hline & Quercus & 1 & rubra & 1 \\
\hline & Robinia & 9 & pseudoacacia & 9 \\
\hline & Sorbus & 7 & aucuparia & 7 \\
\hline & Ulmus & 26 & procera & 24 \\
\hline & Ulmus & & glabra & 2 \\
\hline & Sub total & & & 1232 \\
\hline
\end{tabular}

slow rate of development and the relatively slow rate of spread of the pest at this site (Straw et al. 2016). Climate is likely to have been the most important of these factors, not only because of its major role in determining the rate of development of A. glabripennis (Keena and Moore 2010), but also the impact it can have on the ability of adults to disperse and infest new host trees. Zhou et al. (1984) found that $A$. glabripennis adults are most active at a range between 28 and $32{ }^{\circ} \mathrm{C}$, conditions that are rare for the UK.

The most infested tree detected at Paddock Wood, an A. pseudoplatanus which by 2012 had 498 exit holes, had not been recognised as infested in surveys between 2009 and 2011, because of the ivy (Hedera sp.) which covered the signs of infestation on the trunk. This demonstrated that where practical, climbing plants such as Hedera need to be removed to improve the probability of detecting signs of $A$. glabripennis.

All of the 66 host trees that were found to be infested at Paddock Wood were in the 'high risk' category of hosts. An analysis of the list of trees removed and infested from Paddock Wood (Straw et al. 2014), shows that 34\% (718 trees of 2133) were in species in which some trees were found to be infested (Table 3), 58\% (1232 trees) were in genera and $66 \%$ were in species (a total of 1415 trees) in which no trees were infested (Table 5). Thus, if the species of trees accounting for $66 \%$ of trees in the infested area had not been removed, it would not have had any impact on the eradication campaign. However, a precautionary approach in determining which trees to remove at Paddock Wood was considered appropriate, to the overall aim of removing all infested trees in the first year. As this was the first UK outbreak, it was uncertain, which trees were potential hosts, so, in view of the fact that a number of campaigns to eradicate A. glabripennis that had gone on for several years, e.g. in New York (first detected 1996) and Gien, France (2003), having a broad list of hosts for removal reduced the risk of an extended outbreak and the associated costs (Eyre and Haack 2017).

The percentage of all host trees that were removed at Paddock Wood (2133 trees), that were found infested (66 trees) was $3.1 \%$, this compares to: $0.5 \%$ of infested trees (19): trees removed (3500) in the initial removal of trees at Murnau in Bavaria, Germany (DG Health and Food Safety 2017); 10\%, 10 infested: 100 removed at Almere, Netherlands in 2010-2011 (EPPO 2021), 0.3\%, 1 infested: 350 initially removed at Winterswijk, in the Netherlands in 2012 and 0.5\%, 1 infested tree and 183 trees removed at Berikon Switzerland (EPPO 2021; Tsykun et al. 2019). This shows that infested trees have often been a small proportion of the trees removed in A. glabripennis eradication campaigns in Europe. If a practical and accurate means of identifying which trees are infested trees were available, the destruction caused by the outbreak response could be greatly minimised. One measure that can be taken to reduce the need for removing host trees is injecting them with insecticides to control any A. glabripennis that are present and to protect them against future infestation. A. glabripennis was detected in Chicago in 1998 and declared eradicated in 2008 (EPPO 2021). In Chicago, the majority (88\%) of the 1771 trees removed were infested, but in addition to the trees removed, 286,227 trees were treated with insecticides. The Chicago eradication programme cost $\$ 6.9$ million (Haack et al. 2010). The cost of the survey work carried out at Paddock Wood in 2012 was estimated to 
be $£ 150,000$ and the cost of felling and burning of trees, administration and public outreach as $£ 500,000$ and the total cost as around $£ 1.9 \mathrm{~m}$ (Straw et al. 2016).

The EU emergency measures (EU 2015) include a list of host genera that need to be removed in the event of A. glabripennis outbreaks: Acer, Aesculus, Alnus, Betula, Carpinus, Cercidiphyllum, Corylus, Fagus, Fraxinus, Koelreuteria, Platanus, Populus spp., Salix, Tilia and Ulmus. Since 2012, reviews of A. glabripennis hosts have been published (Meng et al. 2015; Sjöman et al. 2014; van der Gaag and Loomans 2014). Of all the trees found infested, Acer was the genus with the highest number of infested trees at Paddock Wood. The number of $A$. glabripennis trees by host genera has been gathered for four other outbreaks of A. glabripennis: Gien and Sainte-Anne-Sur-Brivet both in France (Hérard et al. 2006), Cornuda in Italy (Faccoli and
Favaro 2016) and Chicago in the USA (Haack et al. 2006) and presented in Fig. 2. Acer accounted for the majority of trees in three outbreaks and was important in the other two outbreaks. Other important host genera were Betula, Ulmus (in Chicago and at Cornuda), Salix (more important in the European outbreaks), Populus and Fraxinus (Chicago only). These data do not give a true indication of host preference because that will depend on the hosts present in the outbreak areas, but they do provide some indication of the relative importance of the host Genera. A. glabripennis host preference within a genus was seen at Paddock Wood for Acer spp., with $26 \%$ of $A$. pseudoplatanus infested as opposed to $2.6 \%$ of $A$. campestre. Similarly, Dodds et al. (2014) found that $A$. glabripennis reproductive success was higher for Acer rubrum than Acer platanoides and Acer saccharum.

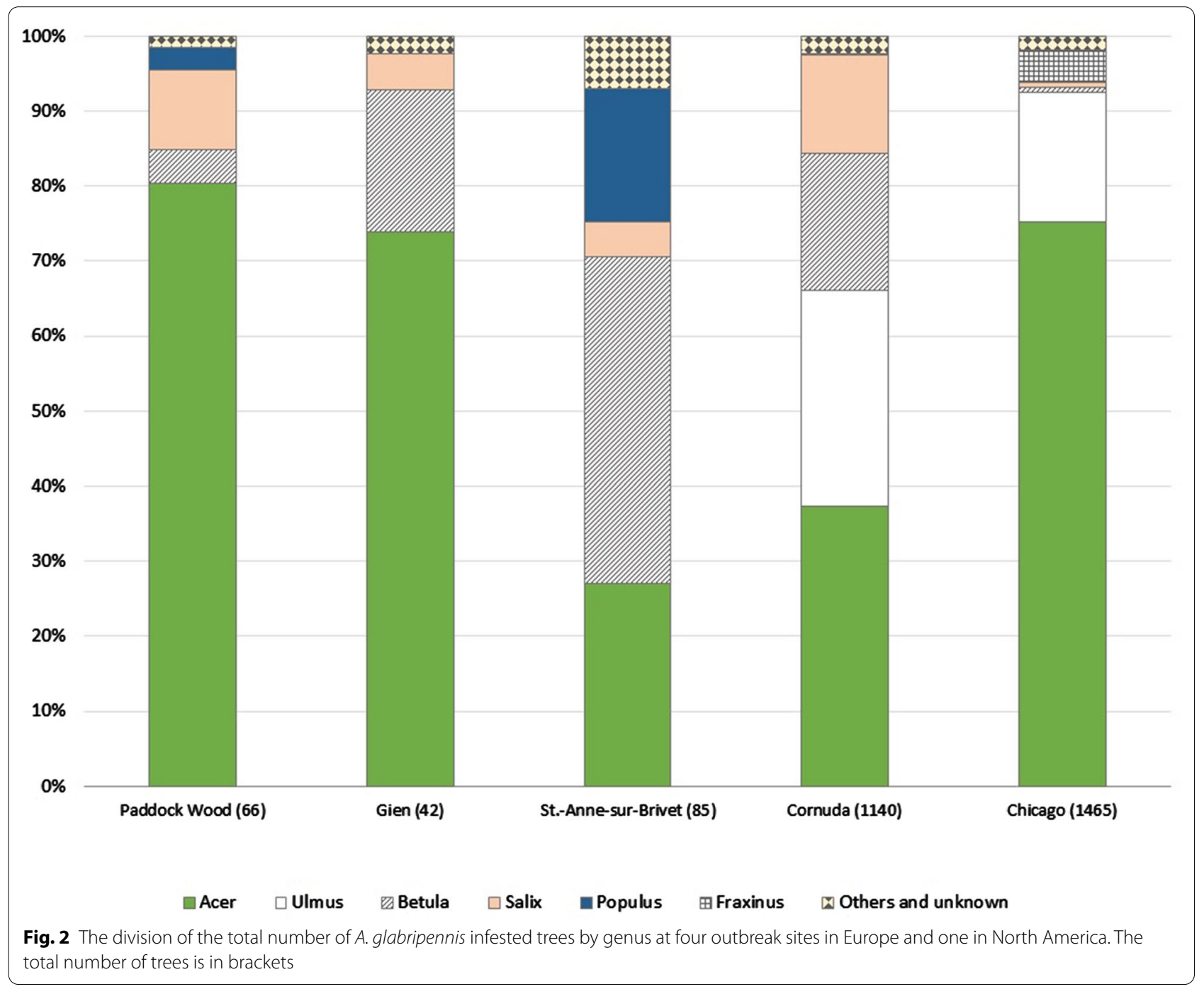




\section{Tree climbers}

Tree climbers from an arboricultural company were employed to inspect the host trees within 100-300 m of infested trees locations in the winters of 2013/2014, 2015/2016 and 2017/2018 (Table 2). This area was chosen for this survey method because it was judged to be the area with trees at greatest risk of being infested. The first survey was approximately 18 months after the infested trees were removed. Before commencing work, the arborists were trained on site by experienced PHSI and Forest Research staff in recognising signs and symptoms of $A$. glabripennis. The tree climbers catapulted ropes over the upper branches of trees to secure themselves and used climbing spikes to ascend the trees. All trunks and branches that were safe to inspect were examined. Mobile Elevated Work Platforms (MEWPs) were also used, together with traffic management, to inspect trees along a major road. An experienced member of the PHSI worked with the team at all times so that any suspicious signs could be checked. Some suspicious signs were photographed and the images checked by the inspector on the ground, others were examined in the tree by the arborist, who removed small sections of bark to check for tunnelling. If the inspector was also suspicious about the signs, the suspect part of the tree was cut down and inspected on the ground for signs of A. glabripennis externally and internally after it had been split open. Any sections of wood which appeared to possibly be infested by A. glabripennis were sent to the research laboratory for further examination. As an example of the workload involved, in the winter of 2013/2014 the arboricultural survey work began on $18^{\text {th }}$ February, and the six arborists worked in two teams for eight weeks.

Suspicious signs were found during these surveys, but none was found to be A. glabripennis. All suspicious signs were diagnosed as (in decreasing order of frequency)leopard moth (Zeuzera pyrina (L.)), secondary infection caused by birds opening wounds to bacterial or fungal infection, goat moth (Cossus cossus (L.)), physical damage and indigenous longhorn beetles (such as-Clytus arietis (L.) wasp beetle). Owing to the size of the trees, some of these signs had not been detected by visual inspection from the ground. Therefore, detection of these signs, provided reassurance that with the additional use of tree climbers, there was a higher probability of detecting $A$. glabripennis if present over using purely visual inspection from the ground. Over the course of 8 weeks in 2014, the first year in which tree climbers were used, six arboriculture staff surveyed 1697 trees. In the first week of the survey, samples of suspicious branches or trunks were taken from one tree in three, but by the final week they were taken from around one tree in 20 reflecting the increasing confidence of the arboricultural staff. The inspector who oversaw the tree climbers' work observed that the whole team was highly motivated and engaged and therefore had high confidence in the ability of the team to detect any suspicious signs and symptoms. A number of the local residents were complimentary about the positive attitude and professionalism of the tree climbing team.

This outbreak was the first in the UK during which arboricultural companies were employed to climb trees and inspect for longhorn beetle damage, and the experience was very positive. Using tree climbers trained to recognise signs of Anoplophora was considered to be an important part of the evidence to support the eventual declaration of eradication because (i) detection rates for A. glabripennis by tree climbers inspecting within tree canopies have been shown to be much higher in other countries than the rates of detection from the ground. In Chicago ground based inspections have been determined to be $32 \%$ effective, whereas in inspections from mobile elevated platforms or by tree climbers have been $57 \%$ and 64\% effective, respectively (Joseph McCarthy, pers. comm.). In Austria, ground based inspections were 30-60\% effective, whereas inspections by tree climbers were 90\% effective (Hoyer-Tomiczek and Sauseng 2012) (ii) at Paddock Wood, the tree climbers found signs similar to those caused by A. glabripennis that had not been detected during ground inspections e.g. damage by $C$. cossus (iii) the efficacy of ground inspections for $A$. glabripennis has been shown to be lower when the damage is above $2.5 \mathrm{~m}$ in the canopy (Turgeon et al. 2010). Tree climbers are able to get closer to the damage when it is high up in trees, increasing the probability of detection.

\section{Detection dog teams}

Detection dogs were first trained in the detection of Anoplophora in Austria in 2009. A team of detection dogs and their handlers travelled from Austria to the outbreak site in the UK in August 2012. Before use in the UK they had also been used in Austria, the Netherlands, Italy, Croatia, Switzerland and Germany. The aims of this visit were to add another method of detection to the methods that had been used already and for inspectors in the UK to evaluate the practicalities of the technique. The dog team worked on the edges of the infested zone to look for previously undetected infested trees (Defra 2013). Trained dogs are able to detect the scent of all stages of Anoplophora sp. in different host species and can also detect galleries, exit holes and overgrown oviposition sites (Hoyer-Tomiczek et al. 2016). The detection team used one dog at a time for around $20 \mathrm{~min}$ at a stretch. The dogs were directed by voice and gesture to the areas to look at. They sniffed around the base of host trees and the ground 
underneath the canopy. When the dogs came across an area with a suspicious scent, they would bark and scratch at the ground. The areas would be re-surveyed with the other dogs to see whether they gave any indications of the presence of A. glabripennis. Only when two or more dogs indicated that the same tree was infested would the handlers record a tree as possibly infested.

The detection dog team surveyed 11.3 hectares over four days. Eight trees were indicated as being potentially infested (4 Salix, 2 Acer, 1 Prunus and 1 Tilia) (Defra 2013). Two of these were felled and destructively sampled. Cut branches from the felled trees were lined up on the ground and two dogs investigated each branch. One of these trees was a Prunus sp. and two of the dogs indicated that the same branch was infested. Inspection revealed an undeveloped oviposition site which had a necrotic area below the bark, a sign typical of $A$. glabripennis. The Austrian team have subsequently found similar undeveloped oviposition pits in Oberaichet and Gallspach (Austria), in Feldkirchen (Germany) and in Brünisried (Switzerland) using detection dogs. A. glabripennis eggs and first instar larvae have been reported to be subject to higher mortality than other juvenile stages, with bacterial and fungal infections being important mortality factors $(\mathrm{Hu}$ et al. 2009). Golec et al. (2018) found that eggs were the most vulnerable life stage with an average of $59 \%$ mortality in four regions of China. At Paddock Wood, $42 \%$ of larvae were found to have died in galleries under the bark before they tunnelled into the wood (Straw et al. 2016). In addition to their work in searching for the beetle, the dog team attracted the interest of a television crew who visited the site to film their work, helping to raise awareness about the pest.

The negative survey results for other surveillance techniques have shown that the infestation level in August 2012 was either very low or zero at the time of the visit of the dog team, and so it was difficult to be conclusive about their efficacy from this trial. However, the effectiveness of detection dogs has been subsequently demonstrated in double blind trials in which A. glabripennis frass was hidden in wooden blocks, or hidden with wood shavings in the ground at the base young poplar trees (Hoyer-Tomiczek et al. 2016). Trials have shown that this technique also has potential for the detection of Agrilus planipennis Fairmaire (Hoyer-Tomiczek and Hoch 2020). The use of dogs for detecting Anoplophora has not been adopted in the UK, but this may be reviewed if there are future outbreaks. By the end of 2020, a total of 117 dogs and 93 dog handlers from Austria, Belgium, Germany, the Netherlands and Switzerland had been trained in the detection of Anoplophora and certified by the teams from the Austrian forestry research centre (BFW) (Ute Hoyer, Pers. Comm.).

\section{Pheromone traps}

Scientists from FERA set up pheromone traps at Paddock Wood each year between 2012 and 2015 and the PHSI set up traps between 2016 and 2018. The traps and lures were both supplied by ChemTica Internacional S.A. (Costa Rica). The traps used were of the cross vane design and they were used in conjunction with a large collection cup optimized for trapping cerambycids. The traps were 'flat pack intercept panel traps', they were black and their surface had been treated with fluon by the manufacturer to make it harder for insects to cling to them. Each panel was about $1 \mathrm{~m}$ tall by $30 \mathrm{~cm}$ across. In the first year, the collection cup was filled with $100 \mathrm{ml}$ of saturated salt (sodium chloride) solution and a few drops of detergent. In subsequent years only water and detergent were used because the salt solution had been found to leak out in high winds causing browning of foliage which made the location of the traps more obvious to passers-by. The lures were pre- loaded with sufficient chemical to last for 90 days; they consisted of separate sachets of (i) male produced pheromone (Zhang et al. 2002) A and B (1:1 ratio) (4-(n-heptyloxy)butanal and 4-(n-heptyloxy)butan1-ol), together with the plant volatiles (ii) carophyllene, (iii) Z3-hexenol, and (iv) linalool, which mimic the natural smell of maple. Sufficient sachets of lure component were purchased to allow for one change/renewal of pheromone lure per trap midway through the deployment. Traps were put in the lower or mid crown of host trees in favoured host trees. Ten traps were set up in 2012, 20 in 2013, 18 in 2014 onwards by placing single traps in a range of host trees (Defra 2013; Hoch et al. 2016). In 2014 onwards, the 18 traps were in 14 Acer spp., 1 Betula, 1 Fraxinus excelsior and 2 Salix sp. The closest distance between neighbouring traps was about $17 \mathrm{~m}$. Traps were set up in or close to the infested zone in 2012 and additional traps were set up further out in 2013 onwards. A modified $5 \mathrm{~m}$ carbon fibre fishing pole was used to loop cord over branches and raise traps to the lower or midcanopy and out of the reach of the general public.

No A. glabripennis or any other species of longhorn beetle were caught in any of the pheromone traps established at the outbreak site each summer between 2012 and 2018. In 2014 and 2015 the most commonly caught non-target species was Byrrhus pilula L. (Coleoptera: Byrrhidae) (pill beetle, $n=314$ ), together with a variety of ladybird beetles (Coleoptera: Coccinellidae) $(n=15, \sim 6$ species) (Hoch et al. 2016).

Although no Cerambycidae were detected in any of the traps at Paddock Wood, the fact that no A. glabripennis were detected by any of the survey methods after 
the destruction of the last infested tree in the summer of 2012 means that this result cannot be used to evaluate efficacy. However, pheromone traps have been used in other outbreaks. In 2014 and 2015, the same traps and lures were used at an outbreak site in Gallspach, Austria (Hoch et al. 2016). One A. glabripennis female was caught on 12th August 2015 and in follow-up survey work an infested tree was discovered demonstrating that pheromone trapping can be a useful tool to support other surveillance methods for Anoplophora. A study using intercept panel traps and the same male produced pheromones and plant volatiles as were used at Paddock Wood and Gallspach demonstrated their efficacy for catching A. glabripennis in China (Meng et al. 2014). EFSA recommend the use of pheromone traps for detecting $A$. glabripennis in areas where it is not known to be present and for the delimitation of outbreaks (EFSA et al. 2019) and they have been used for the detection of A. glabripennis in the USA (Nehme et al. 2014), Germany and Italy (EPPO 2021).

\section{Trap trees}

In April 2015, in the immediate vicinity of the epicentre of the outbreak and within the $100 \mathrm{~m}$ felled area, ten sycamore trees (Acer pseudoplatanus) were planted to act as 'trap trees. The trees were around $3 \mathrm{~m}$ tall and had a diameter at breast height of around $10 \mathrm{~cm}$. In addition, seven Acer pseudoplatanus in a hedgerow were allowed to regrow to act as trap trees. The vegetation around these trees was cut back to facilitate inspection. All 17 trees were monitored monthly throughout the expected adult emergence period and well into the autumn for signs of Anoplophora until eradication was declared in 2019 (Table 2). No A. glabripennis were detected. Trap trees have been used for the detection of Anoplophora in other locations such as Murnau in Bayern, Germany (EPPO 2021).

\section{High risk host trees}

In 2012, a selection of high risk host trees (Table 3) were mapped across the demarcated area and the area surrounding this area. These were trees of species that had been found to be more commonly infested in the outbreak or had been infested at other outbreak locations. These were surveyed at least twice a year as a means of surveying a wider area than would have been possible with the resources available if every host tree was surveyed (Table 2). Initially 33 trees were mapped and designated as high risk host trees, but a further 17 trees were added to these in 2015 giving a total of 50 trees: 27 A. campestre, 11 A. pseudoplatanus, 4 B. pendula, 3 S. caprea, 2 A. hippocastanum, 1 Acer sp., 1 Acer saccharum, and 1 Ulmus sp. No A. glabripennis were detected in the 50 selected high risk host trees.

\section{Pest control procedures}

One of the initial difficulties that faced the inspectors was to correctly locate and identify all the potential host plants. This was a challenging task because of the great variety of plants in the domestic gardens and agricultural environments that surrounded them and because in the early spring in 2012 the deciduous plants did not have any foliage. Before any tree removal could take place, all potential host plants within the infested area were identified to ensure that only host plants were removed. This work was carried out in private gardens by the PHSI. The PHSI sent all plant records to scientists at FERA who created maps of the host plants using ArcGIS. The trees removed were those in the 'high risk' and the 'less favoured' host categories of Table 3 and was limited to plants with a diameter of at least $2 \mathrm{~cm}$ at a point $1 \mathrm{~m}$ above ground level. An arboricultural company carried out all tree felling work in 2012 and a separate company was used to dispose of the felled material. The identity of each tree (in private gardens and other areas) was also checked by FC before trees were felled and FC coordinated all the felling and disposal work. Smaller trees were cut down by working at ground level. Larger trees were initially cut by removing upper parts of the tree by climbing the trees, or where necessary for safety or to avoid damage to property, using a Mobile Elevating Work Platform (MEWP) or 'cherry-picker' (Fig. 3). Stumps of all trees were cut down to ground level and meticulously inspected for signs of $A$. glabripennis. Tree felling started on 16 April and was completed on 3 August 2012. Given the specific circumstances and risks of this outbreak, the felling and disposal programme was managed and funded centrally by the UK Government, to ensure a swift and coordinated response. Before any of the woody material was destroyed it was thoroughly inspected for signs of the presence of A. glabripennis. Any sections of wood with signs characteristic of $A$. glabripennis were cut into $20-40 \mathrm{~cm}$ lengths, put into three layers of containment and transported securely to the Forest Research quarantine laboratory at Alice Holt, Hampshire for further examination. The lengths of wood were stored at $15{ }^{\circ} \mathrm{C}$ in a secure quarantine facility before examination. To examine each section of wood, external signs of damage were recorded, the bark was then removed and finally the wood was split open to reveal any life-stages or damage. All the samples were examined by October 2012.

All remaining plant material, which consisted of sawn sections of trunk, branches and foliage of host trees was burnt on site using an "air curtain" incinerator (Burnboss trailer-mounted portable incinerator, Airburners, 
Palm City, Florida) where a fan blows a curtain of air over and down into the firebox retaining the smoke and overoxygenating the fire (Fig. 4). Burn temperatures of $800{ }^{\circ} \mathrm{C}$ reduce materials to ash of approximately $5 \%$ of the original volume. This method minimised smoke and emissions which was essential given that the incinerator was operating close to two public highways. This operation was delivered by specialist contractors who were on site from 15 May 2012 to 8 August 2012-a total of 79 days. The incinerator worked 7 days a week for c. 10-12 h a day. As a declared 'Plant Health Emergency' an exemption certificate was obtained from the Environment Agency to burn on site because the quantities and duration of burning exceeded usual limits. As the material had not been chipped before burning, the aim had been to get the material burnt before the possible emergence of adult beetles. Using the projections of the 'Pest emergence web tool' (Defra et al. 2020), the projected modelled dates in 2012 for $10 \%$ and 50\% of the A. glabripennis at Paddock Wood based on data by Smith et al. (2004), are July 28th and September $7^{\text {th }}$, respectively. Therefore, it is possible that an adult could have emerged from the waste material, but given that the vast majority would have been disposed of by late July, the risk would have been very low.

Restrictions on the movement of host material were enforced by means of statutory plant health notices issued to individual landowners rather than by statutory measures for the whole area. The area included two garden centres and they were prohibited from selling host plants during the eradication campaign. Maps of the infested and buffer zones were not put into the public domain during the early stages of the outbreak, partly because local residents expressed concerns about the potentially negative association of the outbreak with their properties and community.

\section{Communication, outreach and training materials}

Some of the methods of communication with the public and stakeholders at Paddock Wood were: meetings with local residents in the early stage of the outbreak, meetings with local arborists and businesses, school visits, leaflet drops, interviews with local media and the BBC and press releases on a government website. Communications included the phone number of the PHSI team that dealt with pest reports. The primary school was visited by the local inspector (PHSI) on several occasions to raise awareness and ask pupils to look out for the beetles using learning material from the OPen Air Laboratories (OPAL), a citizen science initiative (OPAL 2020).

In July 2015, a leaflet drop to 11,000 addresses with local Paddock Wood postcodes was undertaken (Fig. 5). This aimed to raise awareness more widely and to ask the public to look for and report any emergent beetles. Early

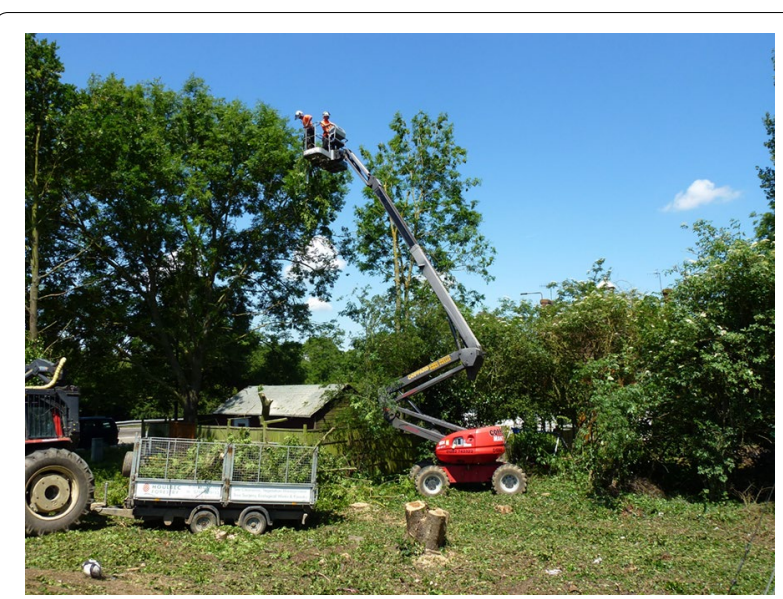

Fig. 3 Removal of trees with the aid of a Mobile Elevated Working Platform (c) Crown Copyright

discussions with the regional depot of the national post service, facilitated an arrangement whereby plant health leaflets were incorporated into planned mail drops to local households. This was both timely, resource effective and less costly than any alternative bespoke solution. It demonstrated the importance of developing a communications strategy at the start of new outbreaks. The communications campaign led to numerous reports of suspect A. glabripennis which were followed up with phone calls, and where necessary, site visits. None of the reports of sightings of $A$. glabripennis from outside the infested area were found to be positive.

The inspectors found that a range of approaches and tools were necessary to communicate with the different groups of stakeholders in the outbreak area and beyond. For the residents outside the immediate area of the outbreak, the inspectors found that awareness declined and so it was necessary to repeat previous means of communication, such as leaflet drops. This outbreak highlighted the need for a more automated means of receiving reports of quarantine pests. A smart phone based recording app was developed by FERA in 2012, but was not widely publicised or used. It has now been superseded by 'Tree Alert' a web based recording system developed by Forest Research in the UK (Forest Research 2020).

At the start of the outbreak, a Canadian guide to signs and symptoms of $A$. glabripennis was used for training and reference (Ric et al. 2007). Over time a number of training approaches and tools were developed, which were also useful for raising public awareness locally and more widely. A training tree was established at Paddock Wood in which simulation exit holes were drilled in appropriate locations which facilitated practice by inspectors. Specimens of adult $A$. glabripennis in acrylic 


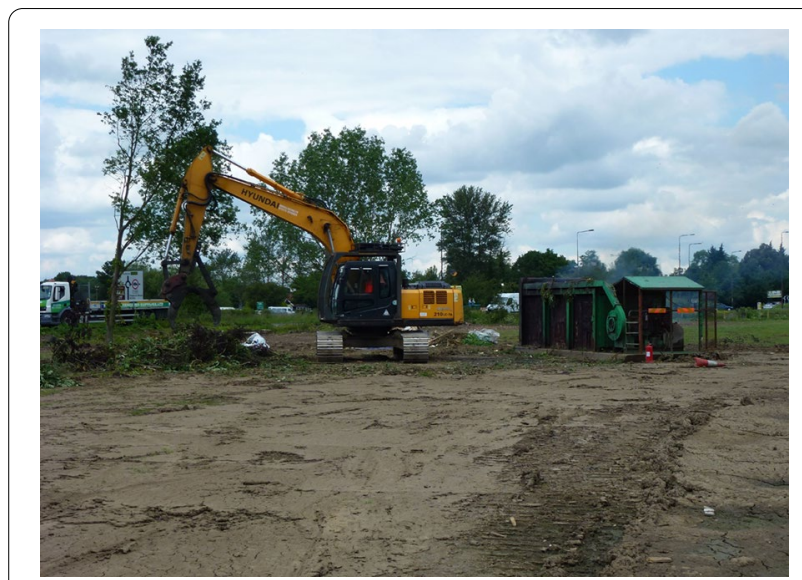

Fig. 4 Destruction of trees using a fan-assisted "air curtain" incinerator (c) Crown Copyright

blocks, together with a large model $A$. glabripennis were commissioned and obtained (Fig. 6). Sectioned wood specimens saved from the initial felling were used to train tree climbers and refresh inspectors from other regions who worked at the outbreak site for short periods. In addition to information on government websites a photographic field guide to A. glabripennis and A. chinensis was produced as part of the Observatree citizen science project and has now been updated (Observatree 2018). A guide to distinguishing the signs and symptoms of Anoplophora from native wood boring species was also developed (Malumphy et al. 2012).

Porth et al. (2015) studied the impact of the eradication campaign at Paddock Wood on the local community by interviewing nine local people who were directly affected by it, and two of the officials involved in the eradication. The interviews took place in May and June 2013, approximately 9 months after the tree removal work was completed. There was a tension between the need to act quickly and decisively to eradicate the pest and the interests of the local residents. The tension between the speed of response needed to manage plant health during an outbreak and the time it would take to consult with stakeholders was also been noted by Mills et al. (2011) in relation to action against the plant pathogen Phytophthora ramorum Werres et al. in the UK. The residents consulted by Porth et al. (2015) understood the need for the eradication campaign, but many were unhappy with how aspects of the operation had been communicated to them and how some of the work had been carried out. Some asked why they were not informed that a beetle had been found in 2009, and only got to hear about it in 2012 when the outbreak was discovered. There was a general feeling of personal loss after the trees had been removed, with

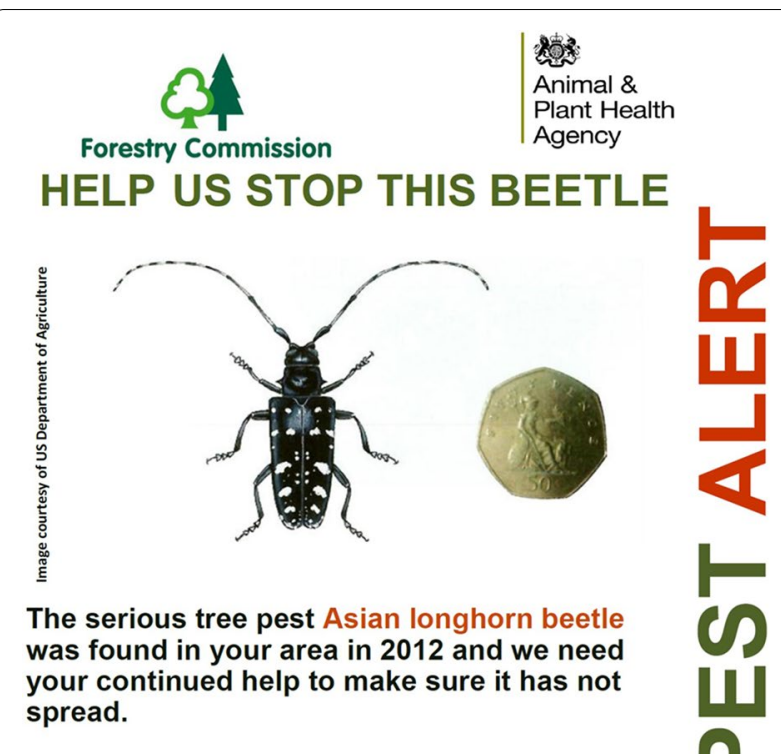

The most obvious signs of damage are circular holes in trunks or branches and adult beetles usually appear between July and October.

If you see any signs of it, contact APHA's Plant Health and Seeds Inspectorate (PHSI) on 01904405138 or planthealth.info@apha.gsi.gov.uk

Thank you for helping to eradicate this threat to our treasured trees

Fig. 5 Front page of publicity leaflet distributed in 2015 @ Crown Copyright

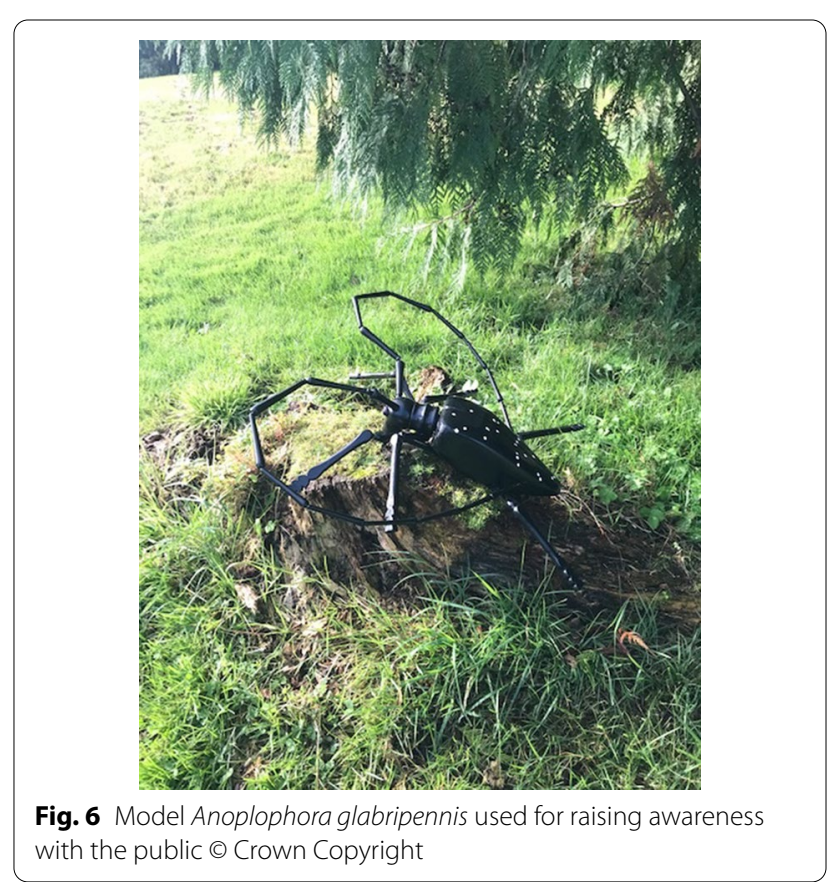


some residents having lost privacy in their property and some commenting on the loss of economic opportunities, as well as the change in the landscape and the impact on wildlife. One of the difficulties of eradication campaigns against A. glabripennis is that it is not possible to reliably determine whether or not a host tree is infested by examining the outside of the tree. This means that many trees have to be cut down in order to detect the minority of trees which are infested. One of the residents was particularly frustrated to lose trees from their garden which were subsequently found to be uninfested. The presence of trees in urban areas can benefit the mental and physical health of local residents (Wolf et al. 2020), but the loss of trees can have negative impacts. The news that the trees on a New York street were going to be removed as part of A. glabripennis eradication work was particularly distressing for one resident, because she had planted one of the trees in memorial to her son who had been killed during military service (Haack et al. 1997).

Porth et al. (2015) recommended that eradication campaigns need to allow the active involvement of all stakeholders and that communication and engagement specialists should be involved in the early part of the eradication campaigns. In a review of media coverage relating to A. planipennis in North America, Clarke et al. (2020) noted the regular use of militaristic language such as the use of a "new weapon" or "battle lines are fully drawn" used to describe new developments. They advised that militaristic language could be counterproductive and that a range of voices should be used to communicate about invasive species because campaigns against them are ineffective without public buy-in. The first report that there was an outbreak at Paddock Wood came from a member of the public and the importance of public awareness and reports of Anoplophora has been seen in other European locations (Ciampitti and Cavagna 2014) and the USA (Poland et al. 1998). Smith et al. (2009) said that the importance of public outreach to the success of A. glabripennis eradication 'cannot be overemphasized'. EPPO has recently published guidance on raising awareness of plant pest issues with the public and this includes advice on communicating via a range of methods including public meetings, social media and videos (EPPO 2019a).

\section{Lessons for future outbreaks}

- The use of specifically trained tree climbers can be an important tool to provide confidence that tree pests have been eradicated

- It is necessary to have an appreciation of the resource (time, people, financial, training) required for deliv- ering an outbreak response, in the initial phase, but also in the follow up surveillance which in this case lasted for 7 years

- For long term campaigns, if there are no offices that can be used locally, it is important to establish an operating base for inspectors to work from in the vicinity of the site

- Outbreaks can be an opportunity for trialling new technologies and approaches for surveillance and recording, allowing a more efficient response to future outbreaks

- The ability to distinguish host plants in domestic, amenity woodland and agricultural settings is important for an effective outbreak response to Anoplophora and other pests

- The relatively cool summers in the UK hindered the development of A. glabripennis and can mean that pest population development can be much slower than in warmer locations leading to protracted eradication campaigns

- Stakeholders should be informed as early as possible when quarantine pests are found. Building relationships and updating stakeholders at appropriate times maintains awareness, summarises progress and provides opportunity for issues to be raised

- It is important to develop a communications strategy tailored to the local situation in the early stages of an outbreak

- The availability of advice tailored to particular quarantine pests such as in the form of a contingency plan can help speed up the initial response to outbreaks

\section{Acknowledgements}

The authors acknowledge the considerable work of colleagues in APHA, Defra, Fera Science Ltd, Forest Research and the Forestry Commission England, arboricultural contractors and members of the public who contributed to this eradication campaign. They are also very grateful to two anonymous referees, plus Dr. Matthew Everatt, Dr. Neil Giltrap and Richard McIntosh (all Defra), Dr. Nigel Straw (Forest Research) and Sarah Thomas (Powys, Wales) for extensive comments and advice on drafts of this manuscript.

\section{Authors' contributions}

$\mathrm{DE}$ - Main drafting and analysis; JB — elements of paper relating to analysis of visual inspection and communication. Both authors read and approved the final manuscript.

Funding

This paper was written by staff funded by Defra.

Availability of data and materials

All data generated or analysed during this study are included in this published article.

\section{Declarations}

Ethics approval and consent to participate Not relevant. 


\section{Consent for publication}

Not relevant.

\section{Competing interests}

The authors declare that they have no competing interests.

\section{Author details}

${ }^{1}$ Department for Environment, Food and Rural Affairs, Room 11G19, Sand Hutton, York YO41 1LZ, UK. ${ }^{2}$ Animal and Plant Health Agency, PHSI, Sand Hutton, York YO41 1LZ, UK.

Received: 1 October 2020 Accepted: 10 March 2021

Published online: 24 March 2021

\section{References}

APHIS. Asian longhorned beetle: Annotated host list; 2015. https://www.aphis. usda.gov/plant_health/plant_pest_info/asian_lhb/downloads/hostlist. pdf. Accessed: 23 Mar 2020.

Brockerhoff EG, Liebhold AM, Richardson B, Suckling DM. Eradication of invasive forest insects: concepts, methods, costs and benefits. NZ J For Sci. 2010;40(Suppl S):S117-36.

Carnegie AJ, Nahrung HF. Post-border forest biosecurity in Australia: response to recent exotic detections, current surveillance and ongoing needs. Forests. 2019;10(4):336.

Ciampitti M, Cavagna B. Public awareness: a useful tool for the early detection and a successful eradication of the longhorned beetles Anoplophora chinensis and A. glabripennis. EPPO Bull. 2014;44(2):248-50.

Clarke MK, Roman LA, Conway TM. Communicating with the public about emerald ash borer: militaristic and fatalistic framings in the news media. Sustainability. 2020;12(11):4560.

Defra, Met Office, Fera Science Ltd. Pest emergence tool; 2020. https://pestemergence.fera.co.uk/. Accessed 20 Jan 2021.

Defra. Supplementary research to support the better detection and identification of Asian longhorn beetle (Anoplophora glabripennis) in the field TH0107; 2013. http://randd.defra.gov.uk/Default.aspx?Menu=Menu\& Module $=$ More\&Location $=$ None\&Completed $=2 \&$ Project $\mid \mathrm{D}=18344$. Accessed 4 Sep 2020.

Defra. Generic contingency plan for plant and bee health in England; 2017. https://www.gov.uk/government/publications/contingency-plan-forplant-and-bee-health-in-england. Accessed 30 Dec 2020.

Defra. Asian longhorn beetle eradicated in the UK; 2019. https://www.gov. uk/government/news/asian-longhorn-beetle-eradicated-in-the-uk. Accessed 10 Feb 2021.

DG Health and Food Safety. Longhorn beetle surveys in the EU: Annual report 2016/2017; 2017. https://ec.europa.eu/food/sites/food/files/plant/docs/ ph_biosec_leg_annual_report_2016-7_anoplophora.pdf. Accessed 29 Sep 2020.

Dodds K, Hull-Sanders H, Siegert N, Bohne M. Colonization of three maple species by Asian longhorned beetle, Anoplophora glabripennis, in two mixed-hardwood forest stands. Insects. 2014;5(1):105-19.

EFSA, Hoppe B, Schrader G, Kinkar M, Vos S. Pest survey card on Anoplophora glabripennis. EFSA Support Publ. 2019;16(12):1750E.

EPPO. PM 3/86 (1) Raising public awareness of quarantine and emerging pests. EPPO Bull. 2019a;49(3):488-504.

EPPO. Eradication of Anoplophora glabripennis from the United Kingdom; 2019b. https://gd.eppo.int/reporting/article-6545. Accessed: 10 Feb 2021.

EPPO. EPPO Global Database; 2021. https://gd.eppo.int/. Accessed 15 Jan 2021.

EU. Commission implementing decision of 1 March 2012 as regards emergency measures to prevent the introduction into and the spread within the Union of Anoplophora chinensis (Forster); 2012. http://eur-lex.europa. eu/legal-content/EN/TXT/?uri=CELEX\%3A32012D0138. Accessed 27 Feb 2016.

EU. Commission implementing decision EU (2015/893) of 9 June 2015 as regards measures to prevent the introduction into and spread within the Union of Anoplophora glabripennis (Mostchulsky); 2015. http://eur-lex. europa.eu/legal-content/EN/TXT/?uri=uriserv:OJ.L_.2015.146.01.0016.01. ENG. Accessed 10 Feb 2021.
Eyre D, Haack RA. Invasive cerambycid pests and biosecurity measures. In: Wang Q, editor. Cerambycidae of the world: biology and management. Boca Raton: CRC Press; 2017. p. 563-618.

Faccoli M, Favaro R. Host preference and host colonization of the Asian longhorned beetle, Anoplophora glabripennis (Coleoptera Cerambycidae), in southern Europe. Bull Entomol Res. 2016;106(3):359-67.

Forest Research. Tree Alert; 2020. https://www.forestresearch.gov.uk/tools-andresources/tree-alert/. Accessed 22 Sep 2020.

Golec JR, Li F, Cao L, Wang X, Duan JJ. Mortality factors of Anoplophora glabripennis (Coleoptera: Cerambycidae) infesting Salix and Populus in central, northwest, and northeast China. Biol Control. 2018;126:198-208.

Haack RA, Law KR, Mastro VC, Ossenburgen HS, Raimo BJ. New York's battle with the Asian long-horned beetle. J For. 1997;95(12):11-5.

Haack RA, Bauer LS, Gao R-T, McCarthy JJ, Miller DL, Petrice TR, et al. Anoplophora glabripennis within-tree distribution, seasonal development, and host suitability in China and Chicago. Great Lakes Entomol. 2006;39(3-4):169-83.

Haack RA, Hérard F, Sun JH, Turgeon JJ. Managing invasive populations of Asian longhorned beetle and citrus longhorned beetle: a worldwide perspective. Annu Rev Entomol. 2010;55:521-46.

Hérard F, Ciampitti M, Maspero M, Krehan H, Benker U, Boegel C, et al. Anoplophora species in Europe: infestations and management processes. EPPO Bull. 2006;36(3):470-4.

Hérard F, Maspero M, Ramualde N, Jucker C, Colombo M, M C, , et al. Anoplophora glabripennis infestation (Col.: Cerambycidae) in Italy. EPPO Bull. 2009;39:146-52.

Hoch G, Schröder T, Weaver R. Further development of risk management for the EC listed Anoplophora species, A. chinensis and A. glabripennis (Anoplorisk-II); 2016. https://www.euphresco.net/projects/portfolio. Accessed 4 Sep 2020.

Hoyer-Tomiczek U, Hoch G. Progress in the use of detection dogs for emerald ash borer monitoring. Forestry. 2020;93(2):326-30.

Hoyer-Tomiczek U, Sauseng G. Alternative detection method for ALB and CLB. Forstsch Aktuell. 2012;55:43-5.

Hoyer-Tomiczek U, Sauseng G, Hoch G. Scent detection dogs for the Asian longhorn beetle, Anoplophora glabripennis. EPPO Bull. 2016;46(1):148-55.

$\mathrm{Hu}$ J, Angeli S, Schuetz S, Luo Y, Hajek AE. Ecology and management of exotic and endemic Asian longhorned beetle Anoplophora glabripennis. Agric For Entomol. 2009;1 1(4):359-75.

IPPC. ISPM 5: Glossary of phytosanitary terms; 2018. https://www.ippc.int/en/ core-activities/standards-setting/ispms/. Accessed 11 Feb 2021.

Keena MA. Anoplophora glabripennis (Coleoptera: Cerambycidae) fecundity and longevity under laboratory conditions: Comparison of populations from New York and Illinois on Acer saccharum. Environ Entomol. 2002;31(3):490-8,

Keena MA. Effects of temperature on Anoplophora glabripennis (Coleoptera: Cerambycidae) adult survival, reproduction, and egg hatch. Environ Entomol. 2006;35(4):912-21.

Keena MA, Moore PM. Effects of temperature on Anoplophora glabripennis (Coleoptera: Cerambycidae) larvae and pupae. Environ Entomol. 2010;39(4):1323-35.

Julius Kuhn-Institut. Leitlinie zur Bekämpfung des Asiatischen Laubholzbockkäfers Anoplophora glabripennis in Deutschland; 2014. http://s4ad420a1 b c62f58c.jimcontent.com/download/version/1355423181/module/71093 62995/name/jKi\%20Leitlinien.pdf. Accessed 22 Sep 2020.

Lingafelter SW, Hoebeke ER. Revision of Anoplophora (Coleoptera: Cerambycidae). Washington DC: The Entomological Society of Washington; 2002. p. 236.

MacLeod A, Anderson H, Follak S, van der Gaag D, Potting R, Pruvos L, et al. External scientific report: pest risk assessment for the European Community plant health: A comparative approach with case studies, Annex P2 ALB Method 3 no RROs; 2012. http://www.efsa.europa.eu/en/supporting/ pub/319e.htm. Accessed 30 Sep 2020.

Malumphy C, Korycinska A, Ostojá-Starzewski J. Differentiating Anoplophora longhorn beetle damage from that of native wood-boring insects; 2012. https://planthealthportal.defra.gov.uk/pests-and-diseases/pest-and-disea se-factsheets/notifiable-pests/. Accessed 5 Feb 2021.

Meng PS, Trotter RT, Keena MA, Baker TC, Yan S, Schwartzberg EG, et al. Effects of pheromone and plant volatile release rates and ratios on trapping Anoplophora glabripennis (Coleoptera: Cerambycidae) in China. Environ Entomol. 2014;43(5):1379-88. 
Meng PS, Hoover K, Keena MA. Asian longhorned beetle (Coleoptera: Cerambycidae), an introduced pest of maple and other hardwood trees in North America and Europe. J Integr Pest Manag. 2015;6(1):1-13.

Mills P, Dehnen-Schmutz K, Ilbery B, Jeger M, Jones G, Little R, et al. Integrating natural and social science perspectives on plant disease risk, management and policy formulation. Philos Trans R Soc Lond B Biol Sci. 2011;366(1573):2035-44.

Nehme ME, Keena MA, Zhang A, Baker TC, Xu Z, Hoover K. Evaluating the use of male-produced pheromone components and plant volatiles in two trap designs to monitor Anoplophora glabripennis. Environ Entomol. 2010;39(1):169-76.

Nehme M, Keena M, Zhang A, Sawyer A, Hoover K. Monitoring Asian longhorned beetles in Massachusetts. In: McManus K, Gottschalk K, editors. Proceedings 21st US Department of Agriculture interagency research forum on invasive species 2010; Annapolis, MD: USDA Forest Service, Northern Research Station, General Technical Report NRS-P-75; 2011. p. 109-10.

Nehme ME, Trotter RT, Keena MA, McFarland C, Coop J, Hull-Sanders HM, et al. Development and evaluation of a trapping system for Anoplophora glabripennis (Coleoptera: Cerambycidae) in the United States. Environ Entomol. 2014;43(4):1034-44.

Observatree. Asian and citrus longhorn beetles; 2018. https://www.obser vatree.org.uk/wp-content/uploads/2018/04/17_0033_One-off-literatureObservatree-Guide-ALB-CLB_wip09.pdf. Accessed 22 Sep 2020.

OPAL. Tree health survey; 2020. https://www.imperial.ac.uk/opal/surveys/treeh ealthsurvey/. Accessed 22 Sep 2020.

Poland TM, Haack RA, Petrice TR. Chicago joins New York in battle with the Asian longhorned beetle. Newsl Michigan Entomolog Soc. 1998;43(4):15-7.

Porth EF, Dandy N, Marzano M. "My garden is the one with no trees:" residential lived experiences of the 2012 Asian longhorn beetle eradication programme in Kent, England. Hum Ecol. 2015;43(5):669-79.

Ric J, de Groot P, Gasman B, Orr M, Doyle J, Smith MT, et al. Training guide: Detecting signs and symptoms of Asian longhorned beetle injury Ontario: Canadian Forest Service Publications; 2007. https://cfs.nrcan.gc. $\mathrm{ca} /$ publications? $\mathrm{id}=26860$. Accessed 22 Sep 2020.

Sawyer A. Infestation dynamics of the Asian longhorned beetle in the United States. In: Gottschalk K, editor. Proceedings 17th US Department of Agriculture interagency research forum on gypsy moth and other invasive species; Annapolis, Maryland: USDA Forest Service, Northern Research Station, General Technical Report NRS-P-10; 2007.

Simberloff D. Today Tiritiri Matangai, tomorrow the world! Are we aiming too low in invasives control? In: Veitch CR, Clout MN, editors. Occassional paper of the IUCN species survival commission No 27, IUCN SSC invasive species specialist group. Gland, Switzerland and Cambridge, UK: International Union for Conservation of Nature; 2002.

Sjöman H, Ostberg J, Hilson J. Review of host trees for the wood-boring pests Anoplophora glabripennis and Anoplophora chinensis: an urban forest perspective. Arboric Urban For. 2014;40(3):143-64.

Smith MT, Bancroft J, Li GH, Gao R, Teale S. Dispersal of Anoplophora glabripennis (Cerambycidae). Environ Entomol. 2001;30(6):1036-40.
Smith MT, Tobin PC, Bancroft J, Li GH, Gao RT. Dispersal and spatiotemporal dynamics of Asian longhorned beetle (Coleoptera: Cerambycidae) in China. Environ Entomol. 2004;33(2):435-42.

Smith MT, Turgeon JJ, De Groot P, Gasman B. Asian Longhorned Beetle Anoplophora glabripennis (Motschulsky): Lessons learned and opportunities to improve the process of eradication and management. Am Entomol. 2009;55(1):21-5.

Straw NA, Fielding NJ, Tilbury C, Williams DT, Inward D. Host plant selection and resource utilisation by Asian longhorn beetle Anoplophora glabripennis (Coleoptera: Cerambycidae) in southern England. Forestry. 2014;88(1):84-95.

Straw NA, Tilbury C, Fielding NJ, Williams DT, Cull T. Timing and duration of the life cycle of Asian longhorn beetle Anoplophora glabripennis (Coleoptera: Cerambycidae) in southern England. Agric For Entomol. 2015;17(4):400-11.

Straw N, Fielding NJ, Tilbury CA, Williams CD, Cull T. History and development of an isolated outbreak of Asian longhorn beetle Anoplophora glabripennis (Coleoptera: Cerambycidae) in southern England. Agric For Entomol. 2016;18(3):280-93.

Tobin P, Kean J, Suckling D, McCullough D, Herms D, Stringer L. Determinants of successful arthropod eradication programs. Biol Invasions. 2014;16(2):401-14.

Tomiczek C, Krehan H, Menschhorn P. Dangerous Asiatic longicorn beetle found in Austria: new danger for our trees? Arboric Urban For. 2002;57(2):52-4.

Tsykun T, Javal M, Hölling D, Roux G, Prospero S. Fine-scale invasion genetics of the quarantine pest, Anoplophora glabripennis, reconstructed in single outbreaks. Sci Rep. 2019;9(1):19436.

Turgeon JJ, Pedlar J, de Groot P, Smith MT, Jones C, Orr M, et al. Density and location of simulated signs of injury affect efficacy of ground surveys for Asian longhorned beetle. Can Entomol. 2010;142(1):80-96.

Turgeon JJ, Orr M, Grant C, Wu Y, Gasman B. Decade-old satellite infestation of Anoplophora glabripennis Motschulsky (Coleoptera: Cerambycidae) found in Ontario, Canada outside regulated area of founder population. Coleopt Bull. 2015;69(4):674-8.

van der Gaag DJ, Loomans AJM. Host plants of Anoplophora glabripennis, a review. EPPO Bull. 2014;44(3):518-28.

Wolf KL, Lam ST, McKeen JK, Richardson GRA, van den Bosch M, Bardekjian AC. Urban trees and human health: a scoping review. Int J Env Res Public Health. 2020;17(12):4371.

Zhang AJ, Oliver JE, Aldrich JR, Wang BD, Mastro VC. Stimulatory beetle volatiles for the Asian longhorned beetle, Anoplophora glabripennis (Motschulsky). Z Naturforsch C J Biosci. 2002;57(5-6):553-8.

Zhou JX, Zhang KB, Lu YZ. Studies on the behaviour and its mechanism of the adult Anoplophora nobilis Ganglbauer. Sci Silvae Sin. 1984;20(4):372-9.

\section{Publisher's Note}

Springer Nature remains neutral with regard to jurisdictional claims in published maps and institutional affiliations.

\footnotetext{
Ready to submit your research? Choose BMC and benefit from:

- fast, convenient online submission

- thorough peer review by experienced researchers in your field

- rapid publication on acceptance

- support for research data, including large and complex data types

- gold Open Access which fosters wider collaboration and increased citations

- maximum visibility for your research: over $100 \mathrm{M}$ website views per year
}

At BMC, research is always in progress.

Learn more biomedcentral.com/submissions 